Violence

\author{
Terrorism and Political Violence
}

\title{
Hatred of the System: Menacing Loners and Autonomous Cells in the Netherlands
}

\section{Jelle van Buuren \& Beatrice de Graaf}

To cite this article: Jelle van Buuren \& Beatrice de Graaf (2014) Hatred of the System:

Menacing Loners and Autonomous Cells in the Netherlands, Terrorism and Political Violence, 26:1, 156-184, DOI: 10.1080/09546553.2014.849932

To link to this article: http://dx.doi.org/10.1080/09546553.2014.849932

\section{Published online: 20 Dec 2013.}

Submit your article to this journal $\square$

Џ Article views: 629

Q View related articles $\square$

View Crossmark data ¿ 


\title{
Hatred of the System: Menacing Loners and Autonomous Cells in the Netherlands
}

\author{
JELLE VAN BUUREN AND BEATRICE DE GRAAF \\ Centre for Terrorism and Counterterrorism, Leiden University, \\ The Hague, The Netherlands
}

\begin{abstract}
In this article, the violent threat emerging from "menacing loners" and autonomous cells in The Netherlands is being historicized and contextualized by providing quantitative and qualitative insight into this threat and illuminating some of the most dramatic incidents. Although beyond the core purpose of this mainly empirical article, some tentative remarks will be presented as possible explanation for both continuity and change. We argue that the shift from political violence originating from groups and networks to political violence perpetrated by individuals, and the shift from ideologically motivated violence to performative violence, are both shifts within a continuum, not radical breaks with the past. It is a difference in degree. Further, we argue that these gradual shifts in types of violence can only be understood as dependent on parallel manifestations of counter-policies, technological developments, and broader trends within society, rather than as attributable to indigenous terrorist developments as such. We postulate a shift from ideologically motivated to performative violence, resulting to a large extent from the possibilities offered by the Internet and social media, and from a broader cultural trend defined as the emergence of the "casting society."
\end{abstract}

Keywords casting society, death threats, hatred of the system, menacing loners, performative violence

Whereas the relatively calm and non-violent character of the Dutch political system and its radical opponents for years has been symbolized by Dutch politicians peddling on their bikes through the city of The Hague without any visible security detail, nowadays The Royal and Diplomatic Protection Department (DKDB) is working overtime in order to protect a range of politicians and other public figures. Responsible for this shift in protection regime are not only the deadly attacks against politician Pim Fortuyn (2002) and opinion maker Theo van Gogh (2004), but also a wave of death threats against national and local politicians. In this article, we will historicize and contextualize the violent threat emerging from "menacing loners" and autonomous cells in The Netherlands by providing quantitative and qualitative insight into this threat and illuminating some of the most dramatic incidents. ${ }^{1}$ In this article, we argue that the assumed double change in current manifestations

Jelle van Buuren is $\mathrm{PhD}$ Researcher and Lecturer at the Centre for Terrorism and Counterterrorism, Leiden University. Beatrice de Graaf is a Full Professor of Conflict and Security History at the Centre for Terrorism and Counterterrorism, Leiden University.

Address correspondence to Jelle van Buuren, Centre for Terrorism and Counterterrorism, Leiden University, P.O. Box 13228, 2501 EE The Hague, The Netherlands. E-mail: g.m.van. buuren@cdh.leidenuniv.nl or b.a.de.graaf@cdh.leidenuniv.nl 
of political violence - from groups and networks to individuals, and from ideologically motivated violence to performative violence - in fact should be understood as gradual shifts within a continuum. Both tightly organized terrorist groups and supposedly "lone wolves" should be seen as ideal types, as poles on a scale on which political violence manifests itself. Ideologically motivated violence and performative violence also should be understood as ideal type categorizations, demarcating a continuum on which different kinds of violence might erupt and conflate.

Further, we argue that these gradual shifts in types of violence can only be understood as dependent on parallel manifestations of counter-policies, technological developments, and broader trends within society. The shift from organized groups or networks to more individual actions should also be considered the result of counterterrorist operations, new legislative definitions, and Internet possibilities rather than attributable to indigenous terrorist developments as such. We postulate a shift from ideologically motivated to performative violence, resulting to a large extent from the possibilities offered by the Internet and social media, and from a broader cultural trend defined as the emergence of the "casting society."

Our research draws extensively on figures and analyses provided by Dutch intelligence services and law enforcement. This of course runs the risk of biased analysis. Whether radical groups would agree with the characteristics the Dutch intelligence service assigned to them of course can be doubted. However, this approach makes it possible to elucidate both continuity and change in the authorities' threat perception of violent political actors. The figures we present should also be treated carefully and with reservation. Due to changing definitions, concepts, and registration regimes, it is impossible to give an exhaustive and comparable quantitative insight into violent political incidents. The figures presented therefore should be considered as no more than a sketch in broad outlines.

\section{Political Violence in the 1960s and 1970s}

The Dutch radical decade started with spontaneous incidents of "ludicrous" happenings in Amsterdam in the mid-1960s. After 1966, the more militant Rode Jeugd (Red Youth) organizations took over, starting in 1967 in Amsterdam, but spreading out to other cities, such as Eindhoven, where the Philips industrial plant was located. The adherents of the Rode Jeugd were, according to Malkki, ${ }^{2}$ radicalized by the Vietnam War and believed that the world was on the brink of revolution and that their struggle fit within the worldwide fight against imperialism and capitalism. The history of the group can be divided into two periods: the protest phase of the years 1966-1970 and the period of resistance with the initiatives for armed struggle in 1970-1973. ${ }^{3}$ The first years of the Rode Jeugd were characterized by "spontaneity and by a very loose type of organization." "Whereas most local branches restrained their action to mostly peaceful acts, the Eindhoven branch was characterized by more provocative and sometimes violent confrontations with the authorities and especially with the police. ${ }^{5}$ Due to a de-radicalising action environment, quarrels about political ideology and the use of violence, the Rode Jeugd split in November 1971. The "moderates" established a short-lived organization called the Rode Jeugd (ML). ${ }^{6}$ The remaining "radicals" of the Rode Jeugd adopted more serious and radical ways of action, including the creation of an organization with legal and illegal branches. ${ }^{7}$ In the course of 1971-1972, the illegal branches were responsible for minor arson attacks - for instance against the car of the police commissioner in Eindhoven - some 
unsuccessful bomb attacks, and a few small bomb attacks against the multinational Philips that succeeded. The attacks were claimed under different names, like the Philips Griekenland Aktiegroep (Philips Greece Actiongroup) and the Revolutionair Volksverzet Nederland (RVN, the Revolutionary People's Resistance of The Netherlands), but were in fact action names of the Rode Jeugd that were used for illegal actions. ${ }^{8}$

Due to arrests by police, fear of infiltrators, and problems inhibiting the establishment of a serious and well-disciplined resistance organisation, Rode Jeugd was formally disbanded in $1974 .{ }^{9}$ However, their key members went on as before with their own network of people and activities. The following years (1974-1976 in particular) were characterized by a search for ways to "contribute to the worldwide revolutionary struggle." 10 Although plans for an urban guerrilla struggle in The Netherlands never completely disappeared from the agenda, the focus was mostly on supporting other groups that had already started the armed struggle, like the Rote Armee Fraktion (RAF) in Germany. Several people from the old cadre of the Rode Jeugd joined an organization called the Rode Hulp (Red Help), established in 1973 to organize solidarity with progressive activists in trouble, and took it over as a legal cover to continue their efforts towards starting an urban guerrilla movement. ${ }^{11}$ In the summer of 1976, a new opportunity presented itself for the radicals around the Rode Hulp as they had the chance to join a training camp of the PFLP (Popular Front for the Liberation of Palestine) in South Yemen. Their intention of again starting up a serious urban guerrilla campaign upon returning to The Netherlands fell apart as it became apparent that the Dutch Security Agency BVD was way too well informed about what they were up to, and after two members were apprehended while on an intelligence mission for the PFLP. On December 31,1976 , the disbandment of the Rode Hulp was announced. ${ }^{12}$

However, after the disbandment of the Rode Hulp, a new organization called Rood Verzetsfront RVF (Red Resistance Front) was established. ${ }^{13}$ The purpose of the RVF was to support those who opposed the "fascist system" by publicizing the resistance against the system and by helping activists who were in trouble. ${ }^{14}$ According to Malkki, in analogy with the Rode Jeugd and Rode Hulp earlier, there seems to also have been initiatives for armed struggle behind the façade of Rood Verzetsfront, but this never really took off. The Rood Verzetsfront continued its existence in the form of a publishing enterprise until the late 1980s. ${ }^{15}$

The Maoist-inspired sabotage acts were flanked by anticolonial outbursts organized by South Moluccan youngsters. The disenfranchised second-generation South Moluccans were children of Moluccan colonial soldiers who had fought for The Netherlands in the Dutch Indies, and because their lives were endangered by the postcolonial republican regime in Indonesia after Independence, had been transported to The Netherlands in 1950, without any prospect of returning or reintegrating into Dutch society. ${ }^{16}$ Their children, raised in secluded Moluccan barrack camps in some centralized areas throughout the country, were not willing to accept the Dutch neglect of their plight any longer and carried out a number of violent actions, including hijacking trains, occupying a primary school, and raiding government buildings. Frustrated by the refusal of authorities to take their feelings of injustice seriously, and inspired by perceived successes of groups like the Black Panthers in the U.S., a growing number of second-generation Moluccan youths became convinced that only a show of force would bring attention to their cause. ${ }^{17}$ Without establishing a formal organization, but as a series of consecutive actions of loose 
social groups (consisting of close friends or relatives), they carried out a number of attacks. Nine hostages lost their lives in these actions that took place between 1970 and 1978. Eight Moluccan activists died during the raids by special forces in order to end the occupations and hijackings. After 1978, violent political activism by Moluccans declined, although the BVD registered rumours that violent actions were still considered possible in the years thereafter. ${ }^{18}$ The fact that the authorities never framed the Moluccan violence as a homogenous public threat, ${ }^{19}$ and responded to the grievances with social services, welfare, dialogue, and integration programmes contributed to the de-escalation of the conflict. Unlike the situation in West Germany, where the second-generation RAF terrorists continued their actions for several years, in The Netherlands the violent political campaigns of the 1970s ended relatively quickly and did not lead to such prolonged campaigns and confrontation as in West Germany.

\section{The Movements of the 1980s}

In the aftermath of the 1970s and the beginning of the 1980s, new political and social movements entered the Dutch scene, especially the anti-militarist movement. The squatters' movement and the anti-imperialist movement were at the forefront of what was referred to as "The Movement": a conglomerate of action groups engaged in squatting, radical anti-militarism, anti-nuclear energy protests, anti-Apartheid actions, anti-racism and fascism, and radical feminist groupings. Individuals and networks that were part of the movement were engaged in innovative, radical, and sometimes violent political actions. The anti-militarist group "Onkruit" (started in 1974) attracted the most attention with spectacular actions, ranging from occupations of military buildings, disturbances at military parades, breaking into and destroying military bunkers, and breaking into different military buildings in order to steal and afterwards publish secret documents. An important dimension of Onkruit's struggle entailed the break-in at military barracks in order to steal and expose secret military plans in which the army prepared itself for actions against targeted individuals and groups within society in times of crises. ${ }^{20}$ From January 1977 till January 1982, about 200 actions were carried out under the name of Onkruit. According to Dutch intelligence, some 500 persons were involved in different actions. Dutch intelligence described Onkruit as "not an action group but rather a group of actions." Further, Dutch intelligence defined it as "a phenomenon that from an organisational viewpoint was hard to describe." ${ }^{21}$ Remarkably, actions were not accompanied by any clear demand towards the authorities. According to Onkruit publications, expressing distaste for current society was more important than an alternative perspective of the future.

The same period gave rise to the squatters' movement. Grounded in concrete actions for affordable housing, the squatters' movement developed itself not only as the centre of a radical counter culture but also created the physical infrastructure for an autonomous life independent from authorities. Major squatted buildings not only had an important symbolic value but also accommodated autonomous printing offices, broadcast stations, restaurants, pubs, music stages, and small businesses. Street confrontations with authorities during evictions from buildings frequently ended in massive and violent street fights. Dutch intelligence described the movement as an "unstructured phenomenon" in which a "colourful collection of different groups and individuals are connected not as much by common goals and strategies, 
Table 1. Violent political incidents from "The Movement," 1980-1989²5

\begin{tabular}{lcccccccccccc}
\hline Motive & 1980 & 1981 & 1982 & 1983 & 1984 & 1985 & 1986 & 1987 & 1988 & 1989 & Total \\
\hline Anti-imperialism & 1 & 0 & 2 & 2 & 1 & 4 & 2 & 2 & - & - & 14 \\
Anti-apartheid & - & - & - & - & 1 & 19 & 19 & 5 & 48 & 47 & 139 \\
Anti-militarism & 2 & 1 & - & 2 & 2 & 2 & 4 & 3 & 2 & 5 & 23 \\
Housing & - & 2 & 4 & 1 & 1 & 4 & - & 1 & 1 & - & 14 \\
Transport & - & - & - & 1 & - & - & - & 1 & - & - & 2 \\
Nuclear energy & - & - & 1 & - & - & 4 & 1 & - & - & - & 6 \\
Bio/gen & - & - & - & - & - & - & - & - & - & 1 & 1 \\
$\quad$ technology & & & & & & & & & & & \\
Animal rights & - & - & - & - & - & - & - & 1 & - & 6 & 7 \\
Not clear & 2 & - & 2 & 4 & 1 & 8 & 10 & 5 & 3 & - & 35 \\
Total & 5 & 3 & 9 & 10 & 6 & 41 & 36 & 18 & 54 & 59 & 241 \\
\hline
\end{tabular}

Note: Buijs, Overtuiging en Geweld. Vreedame en Gewelddadige Acties Tegen de Apartheid (see note 23 below), 173; BVD, Kwartaaloverzicht BVD 1985, 4e Kwartaal 1985 (Den Haag: Author, 1985); BVD, Kwartaaloverzicht BVD 1987, le Kwartaal 1987 Nr. 2048.927 (Den Haag: Author, 1987); BVD, Kwartaaloverzicht BVD 1987, 4e Kwartaal 1987 Nr. 2070.330 (Den Haag: Author, 1987); BVD, Kwartaaloverzicht BVD 1988, 4e Hwartaal $1988 \mathrm{Nr}$. 2094.467 (Den Haag: Author, 1988); Klerks, Terreurbestrijding in Nederland, 1970-1988 (see note 9 below).

as by a life-style characterized by autonomy and individualism."22 Several thousand activists were believed to be part of the movement. The movement was further characterized by a strong negative orientation towards established leftist political parties, civil organisations, and trade unions. Living a life full of action, pleasure, autonomy, and subversion was more important than aspiring to some kind of formal political goal or waiting for the "right class conditions" to arrive. Instrumental violence (the rational use of violence in order to achieve a goal) was mixed with expressive violence: violence intended to shed light on perceived injustices but not targeted at mobilizing popular support. This type of violence could be motivated by anger and indignation about concrete abuses, but also considered as a necessary discharge of tensions, or as an expression of emotional awareness of being in confrontation with the state. ${ }^{23}$ Although the threat to public order was perceived limited by the secret services, the "impertinence and professionalism as well as the frequency of actions" did have a "strong impact on general feelings of insecurity" and therefore intelligence kept a close watch on the movement. ${ }^{24}$ See Table 1.

\section{Fragmentation and the Rise of Anti-Imperialist Struggle}

From within the movement, an anti-imperialist orientation developed during the mid-1980s aimed at uniting the by then fragmentized and isolated remnants of the activist networks from the 1970s. These efforts, however, were strongly criticized and rejected by most of the remaining activists. According to Dutch intelligence, the average activist was too autonomous to follow an all-embracing theory as a guiding principle for future activism. Emotional activism based on individual engagement was deemed more important. ${ }^{26}$ Although the movement was averse to presumed ideological leadership or dogmatism, some general ideas surfaced. Central 
to anti-imperialist ideology was the idea that the capitalist world order is fundamentally unjust, and that this injustice manifests itself in fundamental contradictions between capital and labour, patriarchal exploitation and racist exploitation of Southern countries by Western business and migrant workers in the "Heart of the Beast." The primary targets in the struggle against these injustices were new technologies (genetic technology, biotechnology), population policies, flexible labour policies, city planning, immigration and asylum policies, and European integration ("Europe of Capitalism").

Although anti-imperialism conflicted with the spontaneous and autonomous character of the movement, during the 1980s the anti-imperialist tendency gained strength. This was due to some spectacular and successful actions of the antiimperialist inspired group $R a R a$ (Revolutionary Anti-Racist Action). With a series of arson attacks, the multinational Makro was forced to divest themselves of their activities in South Africa. When RaRa repositioned its actions towards Shell, a wave of smaller actions against Shell gas stations and other Shell affiliates were carried out independently by a plethora of ad hoc groups and individuals. The anti-imperialist tendency was further strengthened when police arrested eight RaRa suspects in $1988 .^{27}$ A wave of solidarity passed through the remainder of the movement. Some action groups launched actions against biotechnology, ${ }^{28}$ city planning, and European integration efforts. After the apartheid regime collapsed, RaRa redirected its actions against Dutch asylum and immigration policies with bomb attacks against the military police in 1990 (responsible for the deportation of illegal aliens and rejected asylum seekers), the Ministry of Justice, the residence of Dutch politician Kosto (responsible for asylum policies in 1991), and the Ministry of Social Welfare and Employment in 1993 (responsible for retrieving illegal migrants). The tactical and strategic goals of their actions were defined by RaRa as a) a contribution to the political awareness of exploitation and oppression, b) showing by the "Propaganda of the Deed" that radical resistance was possible, c) blocking or sabotaging governmental policies or business operations, and d) contributing to the formation of a radical counter force able to resist and change policies. ${ }^{29}$

Dutch Intelligence believed that by 1997 RaRa had ceased to exist. Some 100 persons were thought to form the hard core of the anti-imperialist scene. Some 20 persons within this scene were believed to be core members or close supporters of RaRa. Although especially the bomb attack on Kosto's place could have been lethal, RaRa never aimed at wounding or murdering individuals, as was acknowledged by Dutch intelligence. After the bomb attack against the house of Kosto, it was debated whether politicians should be better protected. The conclusion, however, was that as a matter of principle, public authorities in The Netherlands should not be surrounded by bodyguards and should stay accessible to the public. ${ }^{30}$ Furthermore, the attacks by RaRa were not referred to as terrorism, but were consciously defined as violent political activism (in the same way as earlier the 1970s campaigns by Red Youth and the Moluccans were never publically labelled as terrorism). See Table 2.

At the end of the 1980s, what was left of the once active and lively movement of the 1980s crumbled further down into some small action groups and initiatives. From the start of the 1990s, Dutch intelligence concluded that the threat from the movement had almost disappeared. ${ }^{32}$ Dejection, lethargy, fragmentation, and decline were the keywords used about the remnants of the autonomous left movement. Combined with international developments like the fall of the apartheid regime, the fall of the Berlin Wall, the neoliberal ideologies and policies that 
Table 2. Attacks by RaRa, 1985-1993 ${ }^{31}$

\begin{tabular}{lllll}
\hline Year & \multicolumn{1}{c}{ Place } & Motive & \multicolumn{1}{c}{ Target } & Method \\
\hline 1984 & Amsterdam & Colonialism & Van Heutz Monument & Bomb attack \\
1985 & Groesbeek & Apartheid & Transworld Oil & Arson attack \\
1985 & Duivendrecht & Apartheid & Makro & Arson attack \\
1986 & Amstelveen & Apartheid & Makro & Arson attack \\
1986 & Amstelveen & Apartheid & Van Leer & Arson attack \\
1986 & Duiven & Apartheid & Makro & Arson attack \\
1986 & Duivendrecht & Apartheid & Makro & Arson attack \\
1987 & Nuth & Apartheid & Makro & Arson attack \\
1987 & Zaandam & Apartheid & Makro & Arson attack \\
1987 & Alphen & Apartheid & Shell & Arson attack \\
1988 & Schiedam & Repression & Elba & Arson attack \\
1989 & Hilversum & Apartheid & Shell & Arson attack \\
1990 & Arnhem/Oldenzaal & Asylum & KMAR & Bomb attack \\
1990 & The Hague & Asylum & Ministry Justice & Bomb attack \\
1991 & Grootschermer & Asylum & House of Under & Bomb attack \\
& & & Secretary & \\
1991 & The Hague & Asylum & Ministry of Home & Bomb attack \\
1993 & The Hague & Asylum & Affairs & Ministry of Social \\
& & & Welfare and & Bomb attack \\
& & & Employment &
\end{tabular}

Note: BVD, Kwartaaloverzicht 4e Kwartaal 1989, Nr. 2115986 (Den Haag: Author, 1989); BVD, Kwartaaloverzicht BVD 1989, 2e Kwartaal 1989 Nr. 2105.321 (Den Haag: Author, 1989); BVD, Revolutionaire Anti Racistiese Aktie. De Anti-Imperialistische Stroming in Nederland. No. 2197054-88 (Den Haag: Min BZK, 1993).

triumphed in the 1990s, and the beginnings of the new millennium, the movement of the 1980s and its violent exponents seemed to have reached the end of their life cycle.

\section{Revival of Activism}

At the beginning of the new millennium, authorities detected a resurrection of autonomous actions against racist and fascist organisations and asylum policies, and actions in favour of environmental protection and animal rights. ${ }^{33}$ As activists were believed to work together on these different themes, Dutch Intelligence and Security Agency AIVD ${ }^{34}$ introduced the term "anarcho-extremism." 35 Anarcho-extremists want to change society and are prepared to engage in violent acts to further this goal. Authorities were most worried about radical environmental and animal rights activists. Businesses engaged in the production of meat, mink-breeders, and companies using laboratory animals were the objects of arson attacks. The tendency to pay "house-visits" to intimidate employees of these companies and institutions was seen as a sign of violent radicalisation. According to the AIVD, animal rights activism is both diverse and diffuse, inspired by various motives and perceptions. The majority of the animal rights activists are not inspired by any political ideology, however, but 
by a great emotional attachment to the well-being of animals. The activists are believed to be mostly apolitical persons with a wide range of backgrounds. The purpose of their campaigns is to influence political decision-making on animal rights. It is a movement that according to the AIVD therefore cannot easily be placed under a particular political category. ${ }^{36}$

Compared to the animal rights activists of the 1980s, the "new activists" were less organized and without leadership. They formed rather "a conglomerate of ideas and principles" from which everyone who fights against animal suffering can pick what suits him best. Rather than "follow the leader," the idea is to "follow the doctrine." 37 A small minority of activists - probably no more than a few dozen-was prepared to go to extremes for the benefit of animals. By the mid-1990s, for instance, The Netherlands was confronted with a series of arson attacks throughout the country, committed by two activist organizations operating under the name Right Animal Treatment/Animal Justice Front (RAT/AJF). Dutch intelligence also pointed at so-called individual "amateur activists"; they lead a normal life as an employee, family man, housewife, or student, but after working hours or on weekends, they occasionally - seemingly out of the blue - take part in fierce campaigns, only to disappear into anonymity again afterwards. ${ }^{38}$ So far, however, even this category of activists has kept to the principle that inflicting (serious) material damage is acceptable, but that physical harm to people should be prevented at all times.

The Dutch intelligence agency AIVD further predicted an increase in hard actions against Dutch immigration and asylum policies. This is reflected in an increasing number of arson attacks and so-called "house visits," as well as the "naming and shaming" of policymakers and officials held responsible for the more restrictive asylum policies by publishing their names, addresses, and other details. Extremist actions are believed to be the work of a handful of people operating in tight cells with an ever-changing structure. Targets selected are those responsible for formulating and implementing asylum policy in both public (Immigration and Naturalisation Service (IND), military police, Repatriation and Departure Service of the IND) and private sectors (building contractors and financial institutions involved in construction or renovation work at detention and deportation centres, suppliers and service providers, airlines and private security companies). Three intimidating house visits were registered in 2011, in which paint bombs were thrown, windows were smashed, and cars vandalized. ${ }^{39}$ See Table 3.

\section{Rude Awakening: The Murder of Fortuyn}

The seemingly calm and relatively peaceful political situation in The Netherlands during the 1990s and beginnings of the new millennium was brutally shaken when Dutch politician Pim Fortuyn was murdered in 2002 by Volkert van der Graaf. It was the first political murder seemingly since time immemorial. Fortuyn was an unconventional populist politician with a strong anti-Islam and anti-establishment orientation. He was expected to achieve an unprecedented electoral victory in the coming general elections. His provocative behaviour and sweeping statements against Islam and the "Leftish Church" exposed smouldering dissatisfaction in society with multiculturalism. Further, Fortuyn's critique of the "depoliticized" 1990s - in which the social-democratic party Partij van de Arbeid PvdA (Labour Party), "freed" of its ideological tenets, formed coalitions with the conservative liberal VVD (People's Party for Freedom and Democracy) and implemented neoliberal 
Table 3. Illegal actions of animal rights activists, Right-wing extremism, Left-wing extremism, $2009^{40}$

\begin{tabular}{lccc}
\hline Item & $\begin{array}{c}\text { Animal rights } \\
\text { activism and } \\
\text { extremism }\end{array}$ & $\begin{array}{c}\text { Right-wing } \\
\text { activism and }^{\text {extremism }}{ }^{a}\end{array}$ & $\begin{array}{c}\text { Left-wing } \\
\text { activism and } \\
\text { extremism }\end{array}$ \\
\hline Illegal demonstrations & 0 & 0 & 6 \\
Threats & 9 & 8 & 4 \\
Arson attacks & 0 & 2 & 1 \\
Unlawful entry & 9 & 3 & 48 \\
Assault & 1 & 4 & 0 \\
Public violence & 2 & 10 & 8 \\
Vandalism & 23 & 133 & 17 \\
Of which house visits & 1 & - & 2 \\
Of which liberation of animals & 3 & 2 & 0 \\
Possession of weapons & 0 & 2 & 4 \\
Miscellaneous & 1 & 163 & 88 \\
Total & 45 & & - \\
\hline
\end{tabular}

${ }^{a}$ See paragraph "Anti-Islam Actions by the Extreme Right" for an appreciation of right-wing extremism.

Note: Minister of Home Affairs, Contra Terrorism. 29754 Nr. 189, April 13th 2010 (The Hague: Author, 2010).

policies based on New Public Management - was also shared by parts of the population that felt that the seemingly "autistic" political-administrative complex had lost contact with parts of population. The emotional debates between Fortuyn and the political establishment were saturated with accusations of racism and discrimination. Fortuyn, for instance, spoke of Islam as a "fifth column," called for a Cold War against Islam and pledged the abolition of the anti-discrimination article in the Dutch Constitution. His political competitors compared Fortuyn with Mussolini, Hitler, and Le Pen. After Fortuyn was murdered, his supporters and political successors accused leftist politicians of having created the climate in which the political murder became almost inevitable. Fortuyn was said to be "demonized" by his political opponents, who compared Fortuyn's positions with racist and fascist ideologies; so "the bullet came from the Left." To this day, the reproach of "demonizing" political opponents has a strong connotation and effect in the heavily polarized Dutch political debate on immigration, integration, Islam, freedom of speech, and the role of the "leftist" establishment. ${ }^{41}$

Fortuyn's murderer Van der Graaf was heavily engaged in environmentalism and worked for an organisation that mainly employed judicial tactics in order to force farmers to comply with environmental and animal rights legislation. After his arrest, several newspapers accused Van der Graaf of involvement in the 1996 murder of an environmental civil servant. Police investigation, however, found no evidence for this accusation. Material suited for making explosives was found in Van der Graaf's house, which fed rumours that he was involved in arson attacks against mink breeders. This accusation, however, also could not be proved by police. What exactly his motivations were for murdering Fortuyn never became clear. In his sparse comments on his decision to murder Fortuyn, Van der Graaf pointed at the 
heavily polarized debate in The Netherlands when he declared that he saw Fortuyn as a "danger to society," especially for the vulnerable parts of the population like asylum seekers, Muslims, and people entitled to social security. Van der Graaf stated that his attack was not unpremeditated. He didn't see any other way to stop Fortuyn. ${ }^{42}$ Although police investigations concluded that Van der Graaf acted on his own (an assessment the AIVD endorsed), a general feeling in the society was that leftist politicians, environmental activists, and anti-racist activists were more or less responsible for Fortuyn's death.

\section{Rise of Jihadism in the 1990s}

From the late 1990s, the AIVD for the first time identified the threat emerging from so-called jihadist "transnational networks" composed of immigrated jihadist mujahedeen that engaged in transnational support for the international jihad. Around 1999/2000, Dutch intelligence further identified "internationally-orientated local networks" resulting from the successful radicalisation and recruitment through the transnational networks of mostly Muslim migrants raised and/or born in the West. Thirdly, the AIVD recognized "local-autonomous networks" made up entirely of radicalized young Muslim immigrants. ${ }^{43}$ These jihadists still viewed their activities as part of international jihad, but directed them against their country of residence and operated outside existing jihadist structures. The command structures of the groups that were formed in this stage were spontaneous and very local. Some radicalized youngsters were recruited into the jihad by recruiters with a mujahedeen background that had participated in the jihadist war. The recruitment was defined as an expression of a violent, radical Islamistic movement that has crept into Dutch society. According to the AIVD, this phenomenon should be partly understood as the rise of an Islamic youth subculture in which Islamic dress, symbols, and extreme statements foremost reflect a desire to be part of a group and the expression of an Islamic social identity. ${ }^{44}$

Beginning in 2002, Dutch intelligence monitored closely a group of homegrown jihadi radicals, a network the service internally dubbed as the "Hofstad Group."45 Apart from Mohammed Bouyeri, the murderer of the journalist Theo van Gogh, whose case is discussed later, its core members were under surveillance as was the radical Salafist El Tawheed mosque in Amsterdam. ${ }^{46}$ The members of the Hofstad Group met in and around this mosque and gathered around their mentor Redouan al-Issar (also named "Abu Khaled" or "the Sheikh") who had ties to radical Muslims in Spain and Belgium. ${ }^{47}$ He inspired, amongst others, 17-year-old high school student Samir Azzouzz, who came to the notice of the AIVD in January 2003, when he took the train to Berlin, bound for Chechnya, to join local jihadists in their fight against the Russian forces, but was stopped and arrested at the Ukrainian border and put back on a train to Western Europe. ${ }^{48}$ After his return, Azzouzz's status rose inside local jihadist circles. Together with Ismail Aknikh, he established contacts with Barcelona-based Abdeladim Akoudad, suspected by Moroccan security services of being involved in the Casablanca terror attacks of March 16, 2003. On the basis of intercepted telephone conversations, both Spanish and Dutch authorities believed Azzouzz, Aknikh, and Akoudad were preparing for terrorist attacks. On October 17, 2003, arrests were made in several Dutch cities and apartments raided. ${ }^{49}$ However, as the allegation of terrorism could not be substantiated, the Hofstad members were released after 11 days. It is believed that from 2004 onwards, members of the Hofstad 
network began to conspire against Dutch targets. ${ }^{50}$ The Hofstad Group illuminates what Dutch intelligence called autonomous radicalization, "a spontaneous, interactive and largely autonomous process" through which young men (and, to a lesser degree, young women) embrace radical Islam on their own, with no support from the outside. ${ }^{51}$

\section{The Murder of Theo Van Gogh}

In the early morning of November 2, 2004, Mohammed Bouyeri, a 26-year-old Dutch-Moroccan, born and raised in Amsterdam, awaited moviemaker and opinion maker Theo van Gogh in an Amsterdam street, shot him off his bicycle and slaughtered him with a knife in the middle of the street in front of many witnesses. Bouyeri's action had taken the security services by surprise as he was not considered a main actor in The Netherlands jihadi scene and was not on the list of approximately 150 jihadi radicals the AIVD had identified as a risk to security. ${ }^{52}$ Bouyeri's radical texts calling for violent jihad, disseminated under the name "Abu Zubair," were only taken notice of after the police and AIVD stepped up their investigation into the Hofstad Group after the murder of Van Gogh. ${ }^{53}$ It then turned out that Bouyeri had taken over Abu Khaled's role as spiritual leader and ideologue of the Hofstad Group. Bouyeri slowly radicalized into Islamic militancy from 1999 onwards. The death of his mother in 2001 had a profound impact on this development. ${ }^{54}$ In his testimony, he declared that this bereavement had changed him, leading to a search for truth. His father's re-marriage in the fall of 2003 turned Mohammed Bouyeri further toward radicalism and one can assume that the American invasion of Iraq also contributed to his Islamic militancy. Mohammed Bouyeri started to live according to strict Islamic rules. He grew a beard and began to wear traditional Islamic clothes. He refused to shake hands with women and refused to serve alcohol in the youth centre where he was working as a volunteer. Incidents with police and youth workers and failed attempts by Bouyeri to establish a youth club contributed to this life change. ${ }^{55}$ In Amsterdam Al-Tawheed Mosque, where he began to pray regularly, Bouyeri came to know other Islamic militants like Samir Azzouzz. In his digital statements, he legitimized violence against anyone who offended the Prophet as a religious duty for every Muslim. He also legitimized violence against the Dutch population at large. As Dutch citizens had elected a government that supports the U.S. and Israel, he considered them responsible for the acts of their government. As the Dutch population therefore is at war with Islam, it becomes a legitimate target. At his trial, Bouyeri stated he didn't murder out of hate, but that it was his religious duty. During another trial against Hofstad members, in which Bouyeri was questioned as a witness, he stated in a long but tangled speech that the only possibility of deserving a place in heaven is by killing disbelievers. ${ }^{56}$

Dutch authorities believed that Bouyeri conceived his attacks by himself. Although perhaps some other members of the group were aware of his intentions, his action was a one-man mission. ${ }^{57}$ Bouyeri carefully planned the attack on Van Gogh. Van Gogh was known, among other things, for his anti-Islamist doings and produced the provocative documentary Submission together with the Somali-born Member of Parliament Ayaan Hirsi Ali. Hirsi Ali was protected by Dutch security agencies at that time, but Van Gogh, who had rejected protection, seemed a good alternative for Bouyeri. That Hirsi Ali, however, was the real object of the attack was shown by the "Open letter to Hirsi Ali" Bouyeri stuck with a knife in Van Gogh's chest. ${ }^{58}$ Bouyeri tried to kill the police officers who pursued him, planning to be killed himself in the 
process and become a martyr, but he was shot in the leg and overpowered. After the arrest of Bouyeri, Dutch authorities launched actions against other members of the Hofstad Group, resulting in the arrest of twelve suspects, all charged with membership in a terrorist organisation. However, Azzouzz, who was in jail for his alleged participation in the murder of Van Gogh, and Nourriddin el Fatmi, who had fled the country, continued to plan with others for possible terrorist actions. It took intelligence and law enforcement several more investigations before Azzouzz, El Fatmi, and five others were also prosecuted and convicted for terrorist acts. ${ }^{59}$

Since the turbulence of 2005 and 2006, Dutch intelligence has noticed a drop in the threat of homegrown jihadism. ${ }^{60}$ The threat is believed to be diminished as a result of interventions by law enforcement, intelligence and the administration, internal divisions inside the networks, and the absence of people with leadership appeal. However, some examples of what are referred to as "zelfontbranders" (selfradicalized individuals who go through the entire process of radicalization) occurred during these years. ${ }^{61}$ Bilal L., for instance, was sentenced in 2005 to ten months of prison for publishing video messages in which people were encouraged to decapitate Geert Wilders. There were also rumours that he had planned a bomb attack against the Amsterdam Red Light District. Just a few weeks after his release, he was arrested again on charges of terrorist conspiracy and recruitment for the jihad during his time in prison. He told inmates that he was willing to blow himself up in a public place, was recruiting for jihad, and asked for help in getting ahold of weapons and explosives. Another example is Yehya K., arrested in 2004 because he had threatened Ayaan Hirsi Ali and Geert Wilders with death on the Internet. As the "AIVDkiller," he repeatedly published threatening texts on the Internet and his chat sessions showed that he was making preparations for a bombing. At his home, information on a detonator and booster charge, maps of the city centre of The Hague, information on ammonium nitrate, and addresses of foreign embassies were seized. The court decided that Yehya was in a state of diminished responsibility at the time of his deeds. On February 14, he was sentenced to four months' imprisonment. On November 11, 2008, police arrested a self-radicalized citizen of The Hague. Weapons, ammunition, and a silencer were seized. Although the suspect was convicted for the illegal possession of weaponry, no hard evidence of engagement in terrorist activities could be proven. ${ }^{62}$ During the years 2002-2010, 255 suspects were arrested on terrorist charges; 65 of the suspects were immediately released, 100 suspects were held longer in custody but were never convicted, 33 suspects were expelled, seven suspects were convicted on terrorist charges, and 14 suspects were convicted on other charges. ${ }^{63}$

\section{Anti-Islam Actions by the Extreme Right}

The van Gogh murder was followed by a wave of violent actions against both churches and mosques. "These actions show manifestations of hate and intolerance inside the Dutch society that until recently were not imaginable," AIVD stated. ${ }^{64} 174$ actions were counted during November 2004; 106 of them were directed against Muslim targets and three against churches. Actions varied from plastering swastikas on walls $(16 \%)$, threats $(24 \%)$, bomb alerts $(6 \%)$, street confrontations $(10 \%)$, vandalism $(13 \%)$, arson attacks $(21 \%)$ and assaults $(7 \%)$ to bomb attacks $(2 \%)$. According to the researchers, the wave of violence was reminiscent of the wave of violence following the $9 / 11$ attacks, when 190 violent acts were documented within the two months following the attacks. ${ }^{65}$ 
Whether or not right-wing extremist organisations are responsible for these violent acts is unclear. Right-wing extremism, in its fascist or neo-Nazi manifestation, is traditionally weak in The Netherlands. In the 1980s, for instance, one or two hundred people were believed to be part of organized right extremist networks. A few dozen of these activists were said to be politically active in organisations. ${ }^{66}$ Besides the strong resistance in Dutch society against right-wing extremist organisations, they were traditionally burdened with internal fights and divisions, lack of appealing leaders, and sometimes violent counter activities of anti-fascists. Most organisations only dealt with propaganda and small demonstrations. Most violent incidents with a right-wing extremist character were the responsibility of individual members who were part of an unorganized subculture and not directed by organisations of their leadership. Dutch intelligence used in the beginning of the 1990s the term "unstructured right-extremism" to express the absence of visible planning, coordination, organisation, or the involvement of known right-wing extremist leaders. ${ }^{67}$ During that period, however, an increase in violence directed at "foreigners" was noticed. These violent acts, however, also were not really political or ideologically inspired but based on incoherent, individually determined motives, and interpreted as an expression of a growing societal aversion against multiculturalism. ${ }^{68}$

Although the right-wing extremist scene is known for its obsession with weapons and several members have been arrested for illegal weaponry, this seems more of a cultural fetish than intended for political attacks against political opponents. So far, there are according to the AIVD no indications of a development towards right-wing extremist inspired or motivated terrorism. This does not mean that the possibility of "lone wolves" using violence based on right-wing extremist inspirations or motives can be ruled out. ${ }^{69}$ The broader following seems to be characterized by a certain lack of interest in politics and society, and by a sheer distrust of the current political system. Its recruitment power has decreased over the years as some of their viewpoints have been put on the national political agenda by mainstream political parties. In the integration and Islam debate initiated after the attacks of 9/11, many extreme right-wing viewpoints have been addressed and become mainstreamed. An example is the alleged bankruptcy of the multicultural society. ${ }^{70}$ See Table 4.

Right-wing extremists tried to take advantage of the political success of the strong anti-immigration agendas of Fortuyn and later Wilders. However, besides some isolated incidents in which right-wing extremists succeeded in getting access to the Lijst Pim Fortyn LPF (List Pim Fortuyn) and Partij Voor de Vrijheid PVV (Freedom Party), the right-populist political parties strongly distanced themselves from anything resembling traditional right-wing extremism. According to Dutch intelligence, the most serious threat to democratic order in the beginning of the new decade was a broad societal frustration with multiculturalism from both native and immigrant communities, which could lead to inter-ethnic confrontations. ${ }^{72}$ Right-wing extremist symbols and discourse are used by dissatisfied Dutch youngsters (especially the "Londsdale" youngsters ${ }^{73}$ ) in order to emphasize their identity and in provoking confrontation with migrant youth. Some of these Lonsdale youngsters were believed to be behind recent anti-Islam actions. ${ }^{74}$ Feelings of frustration about multiculturalism could pave the way for further societal polarization. Further, the AIVD stated that the risk that within these groupings of individuals, some can be radicalized into militancy or terrorism cannot be excluded. ${ }^{75}$ However, in 2010 AIVD stated that the Lonsdale subculture had almost disappeared. ${ }^{76}$ After the 
Table 4. Right-wing extremist violent incidents, 1980-1994 ${ }^{71}$

\begin{tabular}{lc}
\hline Year & No. of incidents \\
\hline 1980 & 22 \\
1981 & 13 \\
1982 & 23 \\
1983 & 57 \\
1984 & 62 \\
1985 & 37 \\
1986 & 43 \\
1987 & 13 \\
1988 & 5 \\
1989 & 30 \\
1990 & 37 \\
1991 & 40 \\
1992 & 270 \\
1993 & 352 \\
1994 & 1000 \\
\hline
\end{tabular}

attacks by Anders Behring Breivik, AIVD investigated possible connections between Breivik, his thoughts, and right-wing extremism, but no connections could be established. A group of right extremists were arrested in 2011 for the illegal possession of arms, but the weaponry seemingly was not meant to be used for political targets, but instead for illegal trade. ${ }^{77}$

Besides more or less spontaneous violent confrontations or actions from unorganized individuals from "both" sides, the polarized sphere is foremost represented on the Internet and other new social media. Websites devoted to rightwing extremist or right-populist politics were full of hate messages. In the forum of Polinco - a "politically incorrect forum for people who think" - the tone was set by moderator "Brama":

Nothing will change as long as the spirit and politics of the cowardly left-wing social-democratic lackeys that is everywhere in our society has free rein. There lies the responsibility for the politics of tolerance and gagging that has been preached and imposed for decades! THAT's what is responsible for rewarding the "loonies," for protecting murderers and rapists, for accommodating criminals and thugs, for stimulating moral decay, for destroying the standardisation of prevailing ethical values that have grown for centuries. ${ }^{78}$

The Internet became, in the words of Benschop, a "crucial battlefield" in which political controversies were fought out. ${ }^{79}$ In this, the sharply opposing parties did not restrict themselves to expressing their visions and arguments on their own sites. They also fought each other on neutral sites and entered the sites of the opponent. Right-wing extremists in particular penetrated the web forums of Moroccan sites on a large scale. This gave, according to Benschop, rise to a "virtual civil war." 80 But as much as the digital "bigmouths" from extreme right, left, and jihadist 
affiliations called for civil war, bomb attacks, murder, and revolution, the overwhelming majority of them turned out to be no more than keyboard warriors.

From 2010 onwards, Dutch intelligence introduced the new category "AntiIslamism" as a referent for actions emanating from anti-Islam or anti-jihadist circles that turn both against multiculturalism and the Left. The Breivik attacks were the reason for this new interest, as they showed that attacks by radicalized individuals were not perpetrated only by jihadist terrorists. Anti-Islamism in The Netherlands is, however, perceived to be foremost a digital discourse without any real practical consequences. One of the few activities actually carried out was by the short-lived Dutch Defence League, an organisation consisting of one active person. ${ }^{81}$

\section{Death Threats Against Politicians}

One special manifestation of the political and social turbulence since the murder of Fortuyn was the strong increase in threatening messages - mostly digital - towards a range of politicians, administrators, and other public officials. An inventory by the department of Home Affairs showed that more than one thousand death threats (letters containing bullets, threats by telephone, and hate mail) against politicians were made during the period May 6, 2004 to May 28, $2004 .{ }^{82}$ Research into the past conducted by Frank Bovenkerk in 2005, however, revealed that threats against politicians were not as new as it seemed; public authorities have been the object of aggression for decades. Respondents came up with examples of death threats from twenty or thirty years ago. ${ }^{83}$ Bovenkerk argued that there is however a difference in the way public authorities reacted to threats and political violence. Authorities were traditionally inclined to ignore the involved individuals as harmless quarrel mongers and choose deliberately not to give any public attention to the threats in order not to give other "lunatics" the inspiration to come up with the same idea. ${ }^{84}$ Further, threats and actions against politicians and other public figures used to be "instrumental": motivated by concrete political or societal grievances and aimed at changing policies. Nowadays, threats seem to be more "expressive": symbolic actions in which perpetrators just want to work off their resentment or anger aroused by politicians and administrators. ${ }^{85}$

A special police squad (Team Threatened Politicians (TBP)) was installed in 2004 in order to investigate and prosecute the perpetrators. See Table 5.

Based on in-depth research of 351 cases in which the perpetrators (167) were traced by police, researchers drew up a typology. See Table 6 .

According to the researchers, none of the suspects intended to execute their threats. The majority of the "street language" threats are directed at PVV-leader Geert Wilders and originate from young, mostly Moroccan-Dutch youth, motivated by frustration, anger, or just acting tough. Intervention by police is almost always sufficient to stop the threats. The category "confused-frustrated" seemed to pose

Table 5. Reporting of threats against politicians, 2005-2010 86

\begin{tabular}{lccccccc}
\hline Year & 2005 & 2006 & 2007 & 2008 & 2009 & 2010 & Total \\
\hline Number & 96 & 249 & 245 & 257 & 186 & 201 & 1234 \\
\hline
\end{tabular}

Note: NCTB, Individuele bedreigers van publieke personen in Nederland. Fenomeenanalyse en een beleidsverkenning (Den Haag: Author, 2010), 51. 
Table 6. Typology of menacing individuals ${ }^{87}$

\begin{tabular}{lcr}
\hline Type of menacing individual & Number of suspects & Number of threats \\
\hline Street language threats & $103(60 \%)$ & $122(35 \%)$ \\
Confused & $13(9 \%)$ & $125(36 \%)$ \\
Confused-frustrated & $16(10 \%)$ & $26(7 \%)$ \\
Frustrated & $15(9 \%)$ & $18(5 \%)$ \\
Joke/miscellaneous & $7(4 \%)$ & $7(2 \%)$ \\
Denial of guilt & $5(3 \%)$ & $5(1 \%)$ \\
Dismissal & $4(2 \%)$ & $4(1 \%)$ \\
Radical & $2(1 \%)$ & $41(12 \%)$ \\
Blackmailer & $1(1 \%)$ & $2(1 \%)$ \\
Sparking fear & $1(1 \%)$ & $1(0 \%)$ \\
Total & $167(100 \%)$ & $351(100 \%)$ \\
\hline
\end{tabular}

Note: NCTB, Individuele bedreigers van publieke personen in Nederland. Fenomeenanalyse en een beleidsverkenning (Den Haag: Author, 2010), 74-75.

the biggest risk. Their frustration, coupled with social and economic problems, alcoholism or drug abuse, trauma or other psychological problems, and diminished anger control are all considered to be high risk factors that can lead to violent behaviour. ${ }^{88}$ Sometimes these individuals are motivated by conspiracy theories. Lately, the number of threats is diminishing, partly because of the closing of the Hyves-pages of Geert Wilders. 253 threats were reported in 2011, of which 107 were considered to be liable to punishment. ${ }^{89}$

\section{Menacing Loners}

The threat emerging from radicalized individuals, however, only entered the political and public stage in full magnitude in April 2009. Queens Day 2009 changed from the usual celebratory happening into a disaster when a car broke through the police cordons and crashed into a monument just before hitting the bus that carried the Royal Family. The death-defying ride cost the lives of seven spectators; nine others were seriously injured. The incident was broadcasted live on national television. The driver, Karst Tates, was fatally injured and died on his way to the hospital. Police officers at the scene were able to ask Karst Tates some questions before he lost consciousness. According to the officers, Karst Tates admitted that he was deliberately trying to hit the Royal Family. He stated that he hated the monarchy and that Prince Willem Alexander was a racist and fascist. Main media outlets stated that "The Netherlands had lost its innocence." "Fo "First there was the murder of Pim Fortuyn, then the murder of Theo van Gogh. And now an attack on the Royal Family can be added to this. The first millennium of the new century couldn't have started worse," another daily newspaper wrote. ${ }^{91}$ A popular television program, "Rondom 10" [Around 10], that focuses on pressing social problems broadcasted a special program on the events. The program gave room for the stories of people who felt hurt, offended, and frustrated for reasons of sickness, handicaps, personal losses, unemployment, financial problems, and quarrels with official institutions. The program makers concluded: "Our program proved to be an outlet for Dutch citizens who feel dejected and who identified themselves with the despair of Karst Tates." 92 
The government launched several investigations into the events. The government labelled the events formally as an "attack on the Royal Family that has left deep marks in society." 93 Although the responsible authorities had made an inventory of all intelligence and information on "potential disturbers, be it known criticasters of monarchy or fixated and disturbed persons," no information was available on Karst Tates. The investigation into Karst Tates led to the conclusion that he acted alone and that it was "unlikely" that Tates was informed by any ideology or philosophy. He seemed to be "against everything," had some possible affinity with right-wing extremist ideas and old Nordic cultures and rituals, but no clear political engagement. Police concluded that it "was the individual act of a disturbed person, not inspired by any ideology and done without any significant preparations." 94 The Dutch Parliament discussed the findings in January 2010. The Minister of Justice, Hirsch Ballin, declared that government would invest in knowledge development concerning "radicalized individuals." With help from the British government, police and investigation techniques would be developed in which police, intelligence, prosecutors, and mental health care organisations would collaborate in detecting and monitoring "disturbed individuals" with a fixation on "persons, society or the government." 95

During Remembrance Day 2010, with Queen Beatrix and other members of the Royal Family, the prime minister, and the acting mayor of Amsterdam in attendance, another incident occurred. Just before two minutes of silence came to an end, a man dressed up as an orthodox Jew started mumbling and then shouting. Police officers in plain clothes immediately arrested the man and removed him from the place. A person in the public, however, shouted "bomb, bomb, run for your life." This caused a huge panic amongst the public. A person lost his briefcase, resulting in even more panic. Mounted police removed the suspect briefcase from the square (later it turned out the briefcase was totally harmless). People tried to escape the square, but got caught in the enclosures. Sixty-three persons were wounded. The Queen and the other public figures were immediately brought to a safe place, but returned within minutes to the square to carry on with the ceremonies. ${ }^{96}$ The perpetrator turned out to be a man with a history of drunkenness, drug addiction, and mental health problems. He declared he had shouted because he was angry that he couldn't reach his favourite pub at the other end of the square. When the authorities invented some judicial novelties to keep the man-who by then was publicly known as the "Dam-shouter" - as long as possible in custody, criticism arose from the side of judicial experts. They rejected the claim of the authorities that the man should be prosecuted for an attempt to "attack the Queen" and suggested this was just done as a deterrent and some kind of a "public revenge" for the incident at Queens Day 2009. Later, the "Dam-shouter" was convicted to eight months of prison; he also was banned from attending Remembrance Day for a period of five years.

Another incident took place at Prinsjesdag, September 2011. On Prinsjesdag, the parliamentary year is opened with a joint session of the two houses. On this occasion, the Queen addresses the joint States in a speech in which she sets forth the outlines for the government's policies for the coming year. The Queen travels from her palace to the parliament in a Golden Coach. Every year, tens of thousands of spectators witness the procession of the Golden Coach. A 29-year-old man, Erwin Lensink, threw an object (a tea light candle) at the Golden Coach while shouting "swindlers, thieves, Nazis, fascists, and traitors." The object hit the Coach, but nobody was wounded. The man was immediately arrested by police officers on the suspicion of 
an attempt to inflict severe personal injury. It turned out the man had a history of mental health problems. Police had known the man before, because he testified after the attack of Karst Tates that he was responsible for that attack. Erwin Lensink was held in custody month after month. The public prosecutor wanted Lensink certified as insane and filed a petition for detention under a hospital order. Lensink stated in court and open letters that he contested the birth rights of the Orange Family. Therefore, he wanted a court order to investigate the DNA structure of the remains of King Willem III (who died in 1702). Further, he accused the monarchy of undemocratic and authoritarian behaviour and engaging in conspiracies with international banking and financial institutions, planning for the New World Order.

\section{Shooting Spree in Alphen Aan Den Rijn}

On April 9, 2011, The Netherlands was shocked by the first shooting spree in its history. A 24-year-old man, Tristan van der Vlis, opened fire at the local mall in the small village of Alphen Aan den Rijn, killing six random bystanders and wounding another sixteen. After the shootings, Van der Vlis killed himself. According to a police reconstruction of the incident, ${ }^{97}$ Van der Vlis suffered from depression and schizophrenia. Raised as a Christian, Van der Vlis started to hear the voice of God and claimed to be "touched" by God. He developed an interest in the paranormal and occult and bought special recording equipment (electronic voice recording devices) in order to be able to speak with ghosts. Van der Vlis developed a strong antipathy against God, whom he held responsible for both the psychological pain he suffered in his life as well as misery around the world. "I've prayed many times but none of my prayers were answered. Therefore I lost my faith," Van der Vlis declared to friends. ${ }^{98}$ Van der Vlis even wrote a "counter Bible." Further, Van der Vlis was fascinated by weapons and shooting sprees, especially the Columbine High School shootings. He was a frequent visitor to websites devoted to shooting sprees abroad. As a legitimate member of a gun club, he was able to acquire weapons and ammunition. In September 2006, his parents found a farewell letter from their son. They warned the mental health authorities, leading to a short hospitalization of Van der Vlis. After 2006, Van der Vlis tried on two occasions to kill himself. Police hypothesized that two trigger events were of importance. Van der Vlis lost his job during 2011 and also lost his electronic voice recorder. Further, he suffered from chronic insomnia. There is some evidence that Van der Vlis prepared his act carefully. According to the Public Attorney, Van der Vlis became more angry with God and the world during 2011 and saw no other solution than taking his own life after "punishing God" by making innocent bystanders suffer. As Van der Vlis understood people to be "God's children," he believed he could hurt God by killing people. ${ }^{99}$

\section{"Hatred Against the System"-A New Typology}

During the course of 2009-2011, policies and measures concerning the phenomenon of radicalized individuals were being discussed and implemented by the authorities. The incidents on Queen's Day, Remembrance Day, and Prinsjesdag by now functioned as signifiers for the problem of radicalized and confused individuals. The alleged disturbed state of mind of these perpetrators was being emphasized in policy documents and paved the way for an approach in which police and justice work closely together with mental health agencies. The "National Counterterrorism 
strategy 2011-2015"100 defined "menacing loners" as "people who (without any cooperation from others) constitute a threat through deed or word, as a consequence of individually completed processes towards violence." Within this group, a distinction is made between "radicalized individuals" or "lone wolves" (defined as individuals who are inspired, motivated, and sometimes directed by (virtual) networks of a more or less known ideology or religion) and "fixated persons" (who have no clear ideological motivation for their deeds). Within the "fixated persons" group, a differentiation was made between "confused persons" and individuals who are driven by "hatred of the system" and presumed conspiracy theories. The authorities pointed to the fact that in public discourse some doubt about the "intellectual capacities" of these perpetrators existed and consequently there was a tendency to dismiss their acts as isolated incidents. The Dutch government, however, underlined that the targets of these menaces often had an actual or symbolic function as representatives of a social system the menaces despised.

With the newly introduced concept "hatred of the system," the Dutch government hinted at a "general tendency" in the Dutch society to hold the government or politicians responsible for any form of setback in individual life. According to the authorities, some "unfortunate individuals" could believe that this would justify their decision to take the law into their own hands. An attack is therefore not only a form of retribution, but also a form of self-realisation. This is the case when a loner intends to carry out an ultimate deed in the presence of a large audience and thereby reveal himself to be someone who has the power to make life and death decisions. Due to the motivation, the symbolism of the selected target, and the corresponding effects, an act of violence like this against the political and social system has "all the characteristics of a terrorist act," Dutch authorities stated. Further, the government stated that it is often impossible to make a distinction in advance between radicalized individuals and confused or fixated people. "Often it is important to filter the confused people out of this group where possible, and to neutralize the (potential) danger they represent as much as possible.",101

In order to detect "fixated persons" before they can do any harm, different approaches were implemented. The first was increased surveillance of the Internet, in order to signal and detect potential "fixated persons." The second approach was called "personalized isolation": in cooperation with a range of "front-line workers" (police officers, community workers, teachers, sport instructors, youth workers, and family doctors), police and justice authorities are trying to get a grip on the phenomenon of fixated persons in order to steer these persons towards a (mental) health care route. When local or national ceremonies are being held that could attract the attention of these fixated persons, police and health organisations actively try to get these persons off the streets for that day. On the national level, around 175 people are monitored by a special national police unit; 15 of them are closely monitored. In the Rotterdam-Rijnmond region for instance, the regional police force is monitoring around 50 persons. Local networks established in earlier days to signal and counter radicalisation processes of individuals are now being employed to spot the "fixated" individuals. ${ }^{102}$ The policy papers in which this approach was announced pointed specifically at Karst Tates, the "Dam-shouter," and Erwin Lensink. "Individuals who threaten members of the Royal Family or politicians are a new priority in the light of the societal unrest their acts provoke." 103

Dutch intelligence's analysis stated that the digitalisation of society had lowered the threshold for threatening politicians and other public figures. ${ }^{104}$ Dutch intelligence 
also indicated that most menacing individuals have psychological problems or are young adults who want to work off their anger or frustration. The threat represented by these menacing individuals is believed to be low. ${ }^{105}$ Although the threat emerging from jihadist activists against national politicians is also believed to be low, sometimes the combination with mental health problems can pose a real risk. "The fusion of mental health problems, Jihadist body of thought and a fascination for violence can make these persons a potential threat for national security. As sometimes it is unclear what for these persons count as reality and what not, it is extremely difficult to judge how threatening they are."106

\section{Conclusion: Continuity and Change}

In this article, we have sketched the origins, development, and primary characteristics of political violence stemming from individuals and autonomous cells in The Netherlands since World War II. Some striking continuities can be found. First, political violence in The Netherlands has always been the product of loosely knit networks, small cells, or individuals rather than perpetrated by fairly organized and hierarchical groups. Intelligence labelled these phenomena as "hard to describe from an organisational viewpoint," "a group of actions rather than an action group" (the movements of the 1980s), "a conglomerate of ideas and principles," "tight cells with an ever-changing structure" (animal right activists), "spontaneous aggregated grass-roots networks in which every member is free to act on his own" (homegrown jihadism) or as "unstructured extremism" and "individuals that are part of an unorganized subculture not directed by organisations or leadership" (right-wing extremism). Second, the number of individuals belonging to these "communities of belief" 107 that are willing to engage in violent acts was and is very low. Third, the underlying ideological motivations are not always clear and strategic goals are mostly absent. Dutch intelligence described the movements of the 1980 s as "not connected by common goals and strategies, but by a life-style characterized by autonomy and individualism," or "the essence was living a life full of action, subversion, pleasure and autonomy," "a mixture of instrumental and expressive violence"; animal rights extremism is depicted as "both diverse and diffuse," "mostly not inspired by any political ideology"; homegrown jihadists are said "not to be driven by strategic tactical considerations" or "expressing its own social identity in its subculture by the use of Islamic dress, symbols and extreme statements"; right extremists are "not really politically or ideologically inspired but based on incoherent, individual determined motives." The exception to the rule seems to be the anti-imperialist group $R a R a$, which was inspired by a detailed ideological analysis and program that also informed their tactical and strategic targets. $R a R a$ also turned out to be professional in its operations, able to escape police and intelligence, and successful in its attacks insofar as it forced the mother company of the Makro to close its South African interests. Fourth, threats to politicians and public figures have not just entered the scene in the last decade. Although it is not possible to present clear figures, research found that in the 1980s and 1990s those threats were also common.

Changes can also be noted. First, even the anti-imperialist $R a R a$ was believed to have made the deliberate choice not to target individuals in order to wound or kill them. The murders of Pim Fortuyn and Theo van Gogh therefore count as an earthquake in Dutch political violence. Remarkably, the perpetrators Van der Graaf and Bouyeri were never labelled as "lone wolves," although they surely qualified as such. 
Second, Holland witnessed its first shooting spree. Third, the attack by Karst Tates on the Royal Family was inexplicable in terms of motivation, choice of target, and background of the perpetrator, which was interpreted by Dutch policy makers as a sign of a possible new form of emerging violence that could not be understood by existing concepts and analyses. Fourth, violence committed by individuals or small ad hoc cells was long interpreted as a mitigating condition. As long as violence was not directed by organisations and leadership, the threat to democratic order was deemed to be low. Nowadays, the fact that violence originates from individuals is interpreted as an aggravating condition. Fifth, in the past a supposed disturbed state of mind was never used in order to characterize violent activists. Nowadays, a "psychiatric turn" seems to have taken place in which an important part or even the majority of menacing loners is depicted as fixated individuals mostly in need of psychiatric treatment and counseling. At the same time, a "securitization turn" can be noticed in which people with well-documented histories of mental health problems are posited as risks to national security. One should bear in mind that labeling someone as "disturbed" or not is partly a social construction. Both Volkert van der Graaf and Mohammed Bouyeri could have been labeled as "lone lunatics," but this never happened. One could argue that this is the result of the prevailing societal and political context. Before Pim Fortuyn was murdered, his political opponents were already accused of "demonizing" Fortuyn. Critical questions were raised concerning his security and a lack of protection and the political elite were thus held responsible for anything that might happen to Fortuyn. When he was indeed murdered, the popular interpretation of the act that it was not the work of a disturbed loner was already prevalent. In this view, the bullet came from the Left. This scenario was subsequently instrumentalized for political purposes. The murder of Theo van Gogh occurred in the societal context of fear of jihadist terrorism. When Van Gogh was murdered, the scenario of interpreting the act as proof of the serious risk The Netherlands was facing, instead of as the act of a disturbed individual, was already written.

Although beyond the main purpose of this mainly empirical paper, some tentative remarks will be presented as possible explanation for both continuity and change. We argue, based on our empirical observations, that the shift from political violence originating from groups and networks to political violence perpetrated by individuals, and the shift from ideologically motivated violence to performative violence are both shifts within a continuum, not radical breaks with the past. It is a difference in degree. Further, some factors can be assigned as explanations for these shifts. A first important factor can be situated in counter-terrorist policies, legislation and the operational success of intelligence services, law enforcement, and government. These policies have reduced the possibilities of establishing radical groups or networks. As soon as there is any form of organisation and communication, radicals are vulnerable to detection and pro-active disruption of their activities by intelligence services and law enforcement.

Second, the emergence of the Internet and social media enabled the emergence of digital "communities of belief." These digital communities of belief can be considered to be substitute networks or communities that have partly replaced the old face-toface contacts. So what we witness is not so much the lone individual operating completely isolated from society, but a change in the meaning and perception of what constitutes a community or network. ${ }^{108}$ These digital communities can produce and provide ideological frameworks, knowledge concerning tactics, equipment and 
targets, but of greatest importance, inspiration and the idea that one is part of a vivid, supporting community and not alone.

Comparable remarks can be made for the shift towards performative violence. The rise of Internet and social media enable individuals to assemble their own copy-and-paste ideologies that give meaning to their worlds. In an age in which traditional ideologies have lost most of their appeal, alternative signifying frames are attractive for people looking for sense and meaning in a sometimes confusing and complex world. Discomfort, dissatisfaction, rage, or alienation will, compared to earlier days, manifest themselves less as collective political ideologies and institutions and more as personalized ideologies and identities.

Broader cultural shifts are also of importance. Modern times seem to put a premium on self-exhibition. The importance of individual responsibility, authenticity, wealth, celebrity status, and self-expression, the "casting society" or the "personal branding society," paves the way to understanding oneself and presenting oneself to the outside world as a brand ("the brand Me"). The essence of this personal branding is to recommend oneself constantly or to "expose" the self to the outer world. This exposition of the self asks for a reaction, for confirmation by others. Staging a spectacular action allows an individual to attract the attention of the world. Performative violence therefore foremost refers to itself. It is the construction of identity or position through active expression. Performative violence is not directed so much against the world, but clamours for attention from audiences, demands audiences to look intently at the actor/perpetrator, and by doing so recognizing and acknowledging the actor/perpetrator in its very existence and uniqueness. ${ }^{109}$

Finally, the societal and political framing of acts of political violence matters and has changed. As de Graaf has stated for the $1970 \mathrm{~s}^{110}$ and Bakker for the 1980s, ${ }^{111}$ The Netherlands were a much more violent place to live regarding politically motivated arson and bomb attacks by autonomous cells then than now. However, back then authorities deliberately avoided labeling these violent acts as "terrorism." Violent incidents were not linked together to a homogeneous threat discourse of global terrorism. The "terror network" discourse did not make inroads in Dutch politics. No apocalyptic scenarios were invoked, no political witch hunts instigated. On the contrary, thwarted terrorist actions were kept secret and measures were, as far as possible, only discussed in advisory committees of senior prosecutors, police, and the Ministry of Justice. Nowadays, terrorism has become more or less a standard term in the security discourse. In particular, the murder of Theo van Gogh and the emergence of homegrown jihadi activists tremendously affected governmental counter-terrorism efforts. Threat perception therefore is not just a matter of objective figures but is also informed by broader political-cultural changes in society, shocking events, and the meanings attached to them.

The first important societal change is the increasing sensitivity toward everything that is connected with insecurity and risk. Modern societies are dominated by fear, risk, and insecurity and "security" has become a governmental technique to produce meaning and order in society. The loss of social connections, identities, and public morality has put the issue of meaning and significance in the foreground and has created a permanent feeling of existential insecurity in the capillaries of society. ${ }^{112}$ Incidents not only emerge faster and more often into the public consciousness, the political and societal reactions they provoke are also harsher. A second important change is the rise of new technologies leading to changes in visibility, accessibility, and speed. The current public and political attention to menacing 
individuals can partly be explained by the visibility of the threats. We speculate that in earlier days a segment of Dutch society was frustrated and resentful of "politics," and insults and death threats were the order of the day. However, this resentment was hardly noticeable either to the public at large or to authorities, as it was enacted in the private places of home, pub, and barbecue parties. Nowadays, every digital threatening message is visible to anyone with an Internet connection. The accessibility of the Internet also functions to magnify threats. It is easy to find the email addresses or personal Internet pages of politicians and other public figures. But it is also easy to be informed and inspired by the rich discourse of hate that circulates on the Internet. Finally, the speed of the Internet sets a premium on impulsive behaviour. In the past, anyone who wanted to express their anger with politics or who wanted to threaten a politician had first to find a writing paper and a pencil, write down their grievances, buy a stamp, and find out where to send the letter. Nowadays an impulsive and emotional outburst of hate can be made public within seconds with a few mouse clicks.

Shocking events have a profound impact on society's threat perception and the way authorities react to it. The murders of Pim Fortuyn and Theo van Gogh shocked Dutch society to its very foundations. Not only was the fact that politically motivated murders occurred in Holland shocking, but also the idea that this could happen to anyone who spoke out fiercely against multiculturalism or Islam. Further, the 9-11 attacks and the Madrid 2004 and London 2005 bombings deepened a general feeling of risk. As Bakker ${ }^{113}$ stated, in the 1980s no one had to be fearful of becoming a target for activists as long as you did not invest in apartheid, speculate in real estate, or decide to evict a house occupied by squatters. As jihadists turned towards attacking soft targets, every train or metro traveller was felt to be a potential target. In the digitally interconnected world, incidents abroad form part of ordinary people's perceptions. Although twenty years ago Dutch people also were informed for instance of ETA bomb attacks in Spain, it was not believed to impact their own situations. As jihadists target Western society at large, every jihadist attack abroad can deepen the feeling that this could happen to you tomorrow.

Finally, the understandable societal fear of political violence and terrorism can be partly influenced by the meaning authorities attach to incidents. The performative power of counter terrorism policies ${ }^{114}$ influences, for instance, whether attacks or threats by menacing loners or autonomous cells are signified as tragic incidents or as manifestations of a broader threat that society is facing. From an historical perspective, the threat of political violence that The Netherlands is currently facing is quite low. The vast majority of small violent incidents can — as before-be attributed to loose networks, cells, and individuals from different affiliations. Homegrown jihadism has lost most of its threatening capabilities. The death threats that regularly infect the Internet are perhaps reprehensible, but they have never led to concrete preparations for an attack. The recent warning by AIVD ${ }^{115}$ against overestimating the threat of jihadists based on their outspoken appearance on the Internet therefore could be applicable in general to digital bigmouths. Hatred of the system, according to Dutch authorities, is a new tendency within Dutch society, and can also be found widely on the Internet. However, only Karst Tates probably qualifies as an individual who was informed by a diffuse disgust of society, politics, and its main institutions and so took the law into his own hands and executed an attack not only as a form of retribution, but also as a form of self-realisation. Karst Tates has achieved notoriety and will be remembered. Whether he will be portrayed in history 
books as a sad loser or as a representative of a broader violent tendency within Dutch society will of course be decided by history.

Hypothesizing that the radicalisation process remains a social process, more research is needed in order to find out whether autonomous cells, lone wolves, fixated individuals, and individuals informed by "hatred of the system" nowadays are influenced by comparable social processes. For instance, in The Netherlands not only politicians and public authorities receive digital death threats, but almost anyone who speaks publicly about whatever issue, no matter if they are artists, football trainers, soap opera stars, opinion makers, or singer/songwriters, receives such threats. Therefore the question is whether political or ideological anger is an important explanation for the wave of death threats, or that death threats have become a "normalized" repertoire of contention in society and therefore also affect the political domain. Along the same line of reasoning, one can wonder if Karst Tates really hated monarchy so much that he decided to execute an attack against it, or that he was longing for notoriety ("dying in a blaze of glory" in order to be converted from a nobody into a somebody ${ }^{116}$ ) and rightfully estimating that hitting monarchy was the best and fastest way of realizing this. Looking for both continuity and change in (political) violence and carefully contextualizing and historicizing apparently "new" developments therefore seems to be of utmost importance in order to fully understand current manifestations of the violence that society is facing. For scientists and intelligence or law enforcement officials alike, it seems therefore to be of the utmost importance to analyse as factually and precisely as possible whether the current threat of menacing individuals and small autonomous cells is as new or as threatening as it sometimes appears in political and public discourse, and to decide which counter measures are best suited for an approach that is effective, efficient, and in proportion to the real threat level.

\section{Notes}

1. We will not look into violent action committed by foreign organisations on Dutch territory, like the 1971 attack on an oil terminal by El Fatah, the hostage taking of the French ambassador by the Japanese Red Army in 1974, or the 1979 attack by the IRA on the British ambassador. Nor will we pay attention to violence in the course of mass demonstrations, evictions of occupied buildings, and so forth.

2. Leena Malkki, How Terrorist Campaigns End: The Campaigns of the Rode Jeugd in The Netherlands and the Symbionese Liberation Army in the United States (Helsinki: University of Helsinki, 2010), 35.

3. Ibid., 35 .

4. Ibid., 37.

5. Ibid., 39 .

6. Ibid., 45.

7. Ibid., 47.

8. Ibid., 48; BVD, Maandoverzicht [Monthly Review], nr. 4-1979, Nr. 1324.696 (Den Haag: Author, 1977); BVD, Maandoverzicht [Monthly Review], nr. 6-1977, Nr. 1342.580 (Den Haag: Author, 1977); BVD, Kwartaaloverzicht 1e kwartaal 1981 [Quarterly Review, 1st Quarter], Nr. 1538.691 (Den Haag: Author, 1981); Siem Eikelenboom, Niet Bang Om Te Sterven. Dertig Jaar Terrorisme in Nederland [Afraid to Die. Thirty Year of Terrorism in the Netherlands] (Amsterdam: Nieuw Amsterdam, 2007), 141-170; Beatrice de Graaf and Leena Malkki, "Killing it Softly? Explaining the Early Demise of Left-Wing Terrorism in The Netherlands," Terrorism and Political Violence 22, no. 4 (2010): 623-640; Paul Moussault and Jan Lust, Rood Verzetsfront. Aanzetten tot Stadsguerrilla in Nederland. Een Reconstructie [Red Resistance Front. Initiatives towards Urban Guerrilla in The Netherlands] (Breda: Papieren Tijger, 2009). 
9. See Peter Klerks, Terreurbestrijding in Nederland, 1970-1988 [Counterterrorism in the Netherlands, 1970-1988] (Amsterdam: Ravijn, 1989), 217-218; Eikelenboom, Niet bang om te sterven (see note 8 above), 141-148.

10. Malkki, How Terrorist Campaigns End (see note 2 above), 56.

11. Ibid., 57, 59.

12. Ibid., 61. See also Jacco Pekelder, Sympathie voor de RAF. De Rote Armee Fraktion in Nederland, 1970-1980 [Sympathy for the RAF. The RAF in the Netherlands, 1970-1980] (Amsterdam: Mets \& Schilt, 2007), 81-101, 317-319.

13. Malkki, How Terrorist Campaigns End (note 2 above), 65.

14. Ibid., 65.

15. Ibid., 65-66.

16. Martijn Rasser, "The Dutch Response to Moluccan Terrorism, 1970-1978," Studies in Conflict \& Terrorism 28, no. 6 (2005): 483.

17. Ibid., 483.

18. Eikelenboom, Niet bang om te sterven (see note 8 above), 110-140; Martijn Rasser, "The Dutch Response to Moluccan Terrorism, 1970-1978," Studies in Conflict and Terrorism 28, no. 6 (2005): 481-492; BVD, Maandoverzicht nr. 5, Nr. 1339.855 (Den Haag: Author, 1977); BVD, Maandoverzicht nr. 6, Nr. 1342.580 (Den Haag: Author, 1977); BVD, Maandoverzicht $n r .7 / 8, N r .1350 .205$ (Den Haag: Author, 1977); BVD, Kwartaaloverzicht 4e kwartaal, Nr. 1410.798 (Den Haag: Author, 1978); AIVD, Jaarverslag 2000 (Den Haag: Author, 2000).

19. See Notulen Van de Vergadering van Procureurs-Generaal, Fgd. Directeuren van Politie Met het Hoofd van de Binnenlandse Veiligheidsdienst in het Ministerie van Justitie op 23 September 1971 [Notes of the Meeting of the Procuratory-General and Directors of Police With the Head of the Security Service], RA 1972/001 (The Hague: Archive Ministry of Justice, 1971).

20. BVD, Kwartaaloverzicht 2e Kwartaal 1983, Nr. 1679.711 (Den Haag: Author, 1983).

21. BVD, Kwartaaloverzicht Binnenlandse Veiligheidsdienst $1^{e}$ Kwartaal 1982, Nr. 1598.854 (Den Haag: Author, 1982).

22. BVD, Kwartaalbericht BVD 1987, 2e Kwartaal 1987 Nr. 2056.843 (Den Haag: Author, 1987); BVD, Kwartaaloverzicht BVD 1980, 2e Kwartaal 1980 - Nr. 1495.359 (Den Haag: Author, 1980).

23. Frank J. Buijs, Overtuiging en Geweld. Vreedame en Gewelddadige Acties Tegen de Apartheid [Persuasion and Violence. Peaceful and Violent Actions Against Apartheid] (Amsterdam: Babylon/De Geus, 1995), 69.

24. BVD, Kwartaaloverzicht BVD 1985, 2e Kwartaal 1985 (Den Haag: Author, 1985).

25. Buijs, Overtuiging en Geweld (see note 23 above), 173; BVD, Kwartaaloverzicht BVD 1985, 4e Kwartaal 1985 (Den Haag: Author, 1985); BVD, Kwartaaloverzicht BVD 1987, le Kwartaal 1987 Nr. 2048.927 (Den Haag: Author, 1987); BVD, Kwartaaloverzicht BVD 1987, 4e Kwartaal 1987 Nr. 2070.330 (Den Haag: Author, 1987); BVD, Kwartaaloverzicht BVD 1988, 4e Kwartaal 1988 Nr. 2094.467 (Den Haag: Author, 1988); Klerks, Terreurbestrijding in Nederland, 1970-1988 (see note 9 above).

26. BVD, Kwartaaloverzicht BVD 1988, 3e Kwartaal 1988 Nr. 2088.557 (Den Haag: Author, 1988); BVD, Kwartaaloverzicht BVD 1988, 4e Kwartaal 1988 Nr. 2094.467 (Den Haag: Author, 1988).

27. Only one of the arrested suspects was convicted. Due to procedural faults, his original conviction of 6 years was changed in appeal to a conviction of one year. To this very day it is unclear who exactly belonged to RaRa.

28. BVD, Kwartaaloverzicht 3e Kwartaal 1989, Nr. 2110.419 (Den Haag: Author, 1989).

29. Buijs, Overtuiging en Geweld (see note 23 above), 251.

30. Erwin R. Muller, Terrorisme en Politieke Verantwoordelijkheid. Gijzelingen, Aanslagen en Ontvoeringen in Nederland [Terrorism and Political Responsibility. Hostages, Attacks and Kidnappings in the Netherlands] (Arnhem: Gouda Quint, 1994), 378-380.

31. BVD, Kwartaaloverzicht 4e Kwartaal 1989, Nr. 2115986 (Den Haag: Author, 1989); BVD, Kwartaaloverzicht BVD 1989, 2e Kwartaal 1989 Nr. 2105.321 (Den Haag: Author, 1989); BVD, Revolutionaire Anti Racistiese Aktie. De Anti-imperialistische Stroming in Nederland. No. 2197054-88 (Den Haag: Min BZK, 1993). 
32. BVD, Jaarverslag 1991 (Den Haag: Author, 1991); BVD, $2^{e}$ Kwartaalbericht 1990 (Den Haag: Author, 1990).

33. BVD, Jaarverslag 1993 (Den Haag: Author, 1993); BVD, Jaarverslag 1994 (Den Haag: Author, 1994); BVD, Jaarverslag 1995 (Den Haag: Author, 1995); BVD, Jaarverslag 1997 (Den Haag: Author, 1997); BVD, Jaarverslag 1998 (Den Haag: Author, 1998); AIVD, Jaarverslag 2004 (Den Haag: AVD, 2004).

34. The Dutch Security Agency changed its name in 2002 from Internal Security Agency BVD to AIVD: General Intelligence and Security Service.

35. AIVD, Jaarverslag 2011 (Den Haag: Author, 2011).

36. GISS, Animal Rights Activism in The Netherlands: Between Peaceful and Burning Protest (The Hague: GISS, 2004).

37. AIVD, Jaarverslag 2004 (Den Haag: Author, 2004).

38. BVD, Jaarverslag 1997 (Den Haag: Author, 1997); BVD, Jaarverslag 1998 (Den Haag: Author, 1998); BVD, Jaarverslag 1999 (Den Haag: Author, 1999); BVD, Jaarverslag 2001 (Den Haag: Author, 2001); AIVD, Jaarverslag 2002 (Den Haag: Author, 2002); AIVD, Jaarverslag 2010 (Den Haag: Author, 2010); GISS, Animal Rights Activism in The Netherlands (see note 36 above).

39. GISS, The Flames of Resistance: Growing Opposition to Dutch Immigration and Asylum Policy (The Hague: Author, 2010); AIVD, Jaarverslag 2011 (Den Haag: Author, 2011).

40. Minister of Home Affairs, Contra Terrorism. 29754 Nr. 189, April 13th 2010 (The Hague: Author, 2010).

41. For an overview and analysis of the rise of Pim Fortuyn and the turmoil of those days see: Jelle van Buuren, "Holland's Own Kennedy Affair: Conspiracy Theories on the Murder of Pim Fortuyn," Historical Social Research 38, no. 1 (2013): 257-285.

42. LJN: AF7291, Rechtbank Amsterdam, 13/123078-02.

43. GISS, Violent Jihad in The Netherlands: Current Trends in the Islamist Terrorist Threat (The Hague: Ministry of the Interior and Kingdom Relations, 2006), 29; AIVD, Jaarverslag 2003 (Den Haag: Author,).

44. Lorenzo Vidino, "The Hofstad Group: The New Face of Terrorist Networks in Europe," Studies in Conflict and Terrorism 30, no. 7 (2007): 588; GISS, Violent Jihad in The Netherlands (see note 43 above), 36. For other AIVD publications on Jihad see: GISS, From Dawa to Jihad: The Various Threats Posed by Radical Islam to the Democratic Rule of Law (The Hague: Ministry of the Interior and Kingdom Relations, 2004); GISS, The Radical Dawa in Transition: The Rise of Islamic Neoradicalims in The Netherlands (The Hague: Ministry of the Interior and Kingdom Relations, 2007); GISS, Local Jihadist Networks in The Netherlands: An Evolving Threat (The Hague: Ministry of the Interior and Kingdom Relations, 2010).

45. Description of this case is based, amongst others, on the oral pleadings of the National Prosecution in the Hofstad Group case. National Prosecutor's Office, Requisitoir van de officier van Justitie, part I, 23 January 2006 and part II, 25 January 2006; LJN: Case against Mohammed B., AU 0025, Amsterdam District Court, no. 13/129227-04, 26 July 2005; LJN: AV5108, Rotterdam District Court, 10 March 2006 (compilation of verdicts concerning the Hofstadgroep); LJN: BC2576, The Hague Court of Appeal, 23 January 2008 (appeal); LJN: BK5172, Supreme Court, 2 February 2010 (cassation); LJN: BO7690, Amsterdam Court of Appeal, 17 December 2010 (retrial on appeal), Transnational Terrorism, Security \& the Rule of Law, The 'Hofstadgroep,' Deliverable 5, Work package 3, "Citizens and Governance in a Knowledge-Based Society" (2007), http://www.transnationalterrorism.eu/tekst/publications/Hofstadgroep.pdf.

46. NCTb, Salafisme in Nederland [Salafism in the Netherlands] (The Hague: Author, 2008), 25.

47. Vidino, "The Hofstad Group" (see note 44 above), 583.

48. Ibid., 582.

49. Ibid., 583. See also: Emerson Vermaat, De Hofstadgroep. Portret van een Radicaal-Islamitisch Netwerk [The Hofstad Group. Portrait of a Radical-Islamic Network] (Soesterberg: Uitgeverij Aspekt, 2005), 76-77.

50. National Prosecutor's Office, Requisitoir van de officier van Justitie; Verdict in the Hofstad Group case; "The 'Hofstadgroep.",

51. Vidino, "The Hofstad Group" (see note 44 above), 585. 
52. Statement of Interior Minister Johan Remkes during the parliamentary debate on the Murder. Handelingen Tweede Kamer, November 11 2004, No. 22, 1303; Jutta Chorus and Ahmet Olgun, In Godsnaam. Het Jaar van Theo van Gogh [Insjallah. The year of Theo van Gogh] (Amsterdam: Contact, 2005), 200.

53. Albert Benschop, "Chronicle of a Political Murder Foretold: Jihad in The Netherlands," http://www.sociosite.org/jihad_nl_en.php.

54. Chorus and Olgun, In Godsnaam (see note 52 above), 41-85.

55. COT, The 'Hofstadgroep,' Deliverable 5, Work package 3, "Citizens and Governance in a Knowledge-Based Society" (see note 45 above), 4-6.

56. LJN: AU0025, Rechtbank Amsterdam, 13/129227; Chorus and Olgun, In Godsnaam (see note 52 above), 41-85; Vidino, "The Hofstad Group" (see note 44 above), 579-592.

57. Vidino, "The Hofstad Group" (see note 44 above), 587.

58. COT, The 'Hofstadgroep,' Deliverable 5, Work package 3 (see note 45 above), 6; Vidino, "The Hofstad Group" (see note 44 above), 583-584.

59. Vidino, "The Hofstad Group" (see note 44 above), 579-592; COT, The 'Hofstadgroep,' Deliverable 5, Work package 3 (see note 45 above).

60. AIVD, Jaarverslag 2006 (Den Haag: Author, 2006); AIVD, Jaarverslag 2007 (Den Haag: Author, 2007); AIVD, Jaarverslag 2008 (Den Haag: Author, 2008); AIVD, Jaarverslag 2009 (Den Haag: Author, 2009); AIVD, Jaarverslag 2010 (Den Haag: Author, 2010); GISS, Local Jihadist Networks in The Netherlands: An Evolving Threat (The Hague: Ministry of Interior and Kingdom Relations, 2010).

61. Vidino, "The Hofstad Group" (see note 44 above), 588.

62. Edwin Bakker, "Terrorisme en Politiek Gewelddadig Activisme in Nederland" [Terrorism and Political Violent Activism in the Netherlands], Jaarboek Vrede en Veiligheid (2008): 226.

63. Table of terrorist related arrests in The Netherlands since September 11, 2001: http://www.onjo.nl/fileadmin/uploads/BO/be_users/documents/Argos/arrestatie-terrorismetot-2010.pdf.

64. AIVD, Jaarverslag 2004 (Den Haag: Ministerie van Binnenlandse Zaken en Koninkrijksrelaties, 2005).

65. Jaap van Donselaar and Peter R. Rodrigues, ANNEX Monitor Racisme en Extreem-Rechts, Zesde Rapportage: Ontwikkelingen na de Moord op Van Gogh (Leiden/ Amsterdam: Anne Frank Stichting, Onderzoek en Documentatie Universiteit Leiden, Departement Bestuurskunde, 2004).

66. BVD, Jaarverslag 1991 (Den Haag: Leiden/Amsterdam, 1991).

67. Jaap van Donselaar, De Staat Paraat? De Bestrijding van Extreem-Rechts in West-Europa [The State Prepared? Fighting the Extreme Right in West-Europe] (Amsterdam: Babylon/De Geus, 1995), 64.

68. GISS, Right-Wing Extremism and the Extreme Right in The Netherlands (The Hague: Author, 2012).

69. Ibid.; see also “Lone Wolves, ook in Nederland?" Antifascistische Onderzoeksgroep Kafka, http://kafka.antenna.nl/?p=3352.

70. GISS, Right-Wing Extremism and the Extreme Right in The Netherlands (see note 68 above).

71. Donselaar, De Staat paraat? (see note 67 above), 59.

72. AIVD, Jaarverslag 2005 (Den Haag: Author, 2005).

73. "Londsdale" refers to a popular clothing label that for some time was popular in the right-wing extremist scene. According to right-wing extremist skinheads, the combination of the letters NSDA in LONSDALE refers to the NSDAP, the nationalist-socialist party of Adolf Hitler. Although for most youngsters this national-socialist connotation is not the reason for wearing the jackets, the right-wing extremist image sticks.

74. AIVD, Jaarverslag 2004 (Den Haag; Author, 2004); see also: AIVD, "LonsdaleJongeren" in Nederland. Feiten en Fictie van een Vermeende Rechts-Extremistische Subcultuur. Nr. 2381145/01 (Den Haag: Author, 2005).

75. AIVD, Jaarverslag 2006 [Extreme-Right: Body of Thought and Organisations] (Den Haag: Author, 2006).

76. AIVD, Rechts-Extremisme: Gedachtegoed en Groeperingen, https://www.aivd.nl/ onderwerpen-0/extremisme/rechts-extremisme/gedachtegoed/. 
77. AIVD, Jaarverslag 2011 (Den Haag: Author, 2011).

78. Benschop, "Chronicle of a Political Murder Foretold: Jihad in The Netherlands" (see note 53 above).

79. Ibid.

80. Ibid.

81. AIVD, Jaarverslag 2011 (see note 77 above).

82. Frank Bovenkerk, Bedreigingen in Nederland. Verkenning in Opdracht van Politie en Wetenschap [Threats in the Netherlands. Exploration Ordered for by Police and Science] (Utrecht: Willem Pompe Instituut Universiteit Utrecht, 2005).

83. Ibid.

84. Ibid., 51.

85. Ibid., 51.

86. NCTB, Individuele Bedreigers van Publieke Personen in Nederland. Fenomeenanalyse en Een Beleidsverkenning [Individual Threateners of Public Persons in the Netherlands. Analysis of a Phenomenon and Exploration of Policy Options] (Den Haag: $\mathrm{NCTb}, 2010), 51$.

87. Ibid., 74-75.

88. Ibid., 74-75.

89. Openbaar Ministerie, Politici in de Haagse Regio Minder Bedreigd, March 20, 2012, http://www.om.nl/onderwerpen/bedreigingen/@158578/politici-haagse/.

90. Arendo Joustra, "Nederland Verliest Onschuld met Aanslag," Elsevier, April 30, 2009, http://www.elsevier.nl/web/Opinie/Commentaren/232453/Nederland-verliest-onschuldmet-aanslag.htm.

91. "Koninginnedag Zal Nooit Meer Zijn Wat het Altijd Geweest Is," Trouw, May 1, 2009, http://www.trouw.nl/tr/nl/4324/Nieuws/article/detail/1147961/2009/05/01/ Koninginnedag-zal-nooit-meer-zijn-wat-het-altijd-geweest-is.dhtml.

92. See www.rondom10.nl, broadcast from May 2, 2009.

93. Kamerstukken, Koninginnedag 2009. Verslag van Een Algemeen Overleg. 32054, $\mathrm{nr} .1$ (Den Haag: Ministerie BZK, 2008-2009); NCTb, Onderzoek Functioneren Stelsel Bewaken en Beveiligen Koninginnedag 2009 (Den Haag: Author, 2009). Note that the NCTb is consequently speaking of an "incident" rather than an "attack."

94. KLPD, Onderzoeksrapportage Koninginnedag 2009. Bevindingen Recherche Onderzoek Dienst Nationale Recherche (Driebergen: Author, 2009).

95. Kamerstukken, Koninginnedag 2009. Verslag van Een Algemeen Overleg. 32054, nr. 22009 (Den Haag: Ministerie BZK, 2010).

96. For video footage of the incident see http://www.novatv.nl/page/detail/uitzendingen/ 7798/Persconferentie+naar+aanleiding+incident+tijdens+dodenherdenking\#.

97. Openbaar Ministerie, Samenvatting TGO Onderzoek Komeet Naar Schietpartij Alphen a/d Rijn op 9 April 2011 (Den Haag: Author, 2011).

98. http://nos.nl/artikel/255240-tristan-wilde-god-straffen.html.

99. Openbaar Ministerie, Samenvatting TGO Onderzoek Komeet naar schietpartij (see note 97 above).

100. NCTb, National Counterterrorism Strategy 2011-2015 (The Hague: Author 2011), http://english.nctb.nl/current_topics/reports/.

101. Ibid.

102. Kamerstukken, Terrorismebestrijding. Verslag van Een Algemeen Overleg. 29754 nr. 208 (Den Haag: Ministerie van BZK, 2011-2012).

103. "KLPD Focust Ook op Zogenoemde Solistische Dreiger," Spits, January 4, 2012.

104. AIVD, Jaarverslag 2009 (Den Haag: Author, 2009).

105. AIVD, Jaarverslag 2010 (Den Haag: Author, 2010).

106. Ibid.

107. COT, Lone Wolf Terrorism. Final Draft. Case Study for Work Package 3, "Citizens and Governance in a Knowledge-Based Society" (2007).

108. Jelle van Buuren, "Performative Violence? The Multitude of Lone Wolf Terrorism," Terrorism: An Electronic Journal and Knowledge Base 1, no. 1 (2012): 1-25.

109. Ibid.

110. Beatrice de Graaf, Evaluating Counterterrorism Performance: A Comparative Study (London/New York: Routledge, 2011). 
111. Bakker, "Terrorisme en Politiek Gewelddadig Activisme in Nederland" (see note 62 above), 226.

112. Zygmunt Bauman, Liquid Fear (Cambridge: Polity Press, 2006); Ullrich Beck, Risk Society: Towards a New Modernity (London: Sage, 1992); Hans Boutellier, De Veiligheidsutopie. Hedendaags Onbehagen en Verlangen Rond Misdaad en Straf [The Safety Utopia. Unease and Longing in the Context of Crime and Punishment] (Den Haag: Boom Juridische Uitgevers, 2005); Frank Furedi, Culture of Fear: Risk-Taking and the Morality of Low Expectations (London: Cassell, 1997); Frank Furedi, Culture of Fear Revisited (London: Continuum Press, 2006).

113. Bakker, "Terrorisme en Politiek Gewelddadig Activisme in Nederland" (see note 62 above), 226.

114. De Graaf, Evaluating Counterterrorism Performance: A Comparative Study (see note 110 above).

115. GISS, Jihadism on the Web: Breeding Ground for Jihad in the Modern Age (The Hague: Ministry of the Interior and Kingdom Relations, 2012), 20.

116. R. A. Fein and B. Vossekuil, "Assassination in the United States: An Operational Study of Recent Assassins, Attackers, and near-Lethal Approachers," Journal of Forensic Sciences 44, no. 2 (1999): 321-333. 